\title{
Assessment of Sustainability Indicators of Thermoelectric Power Generation in Cameroon Using Exergetic Analysis Tools
}

\author{
Moungnutou Mfetoum Inoussah $^{1 *}$, Moukengue Imano Adolphe1, Lissouck Daniel ${ }^{2}$ \\ ${ }^{1}$ University Institute of Technology of Douala, University of Douala, Douala, Cameroon \\ ${ }^{2}$ Department of Renewable Energy, Higher Technical Teachers' Training College of KUMBA, University of Buea, \\ Kumba, Cameroon \\ Email: `inoussah@gmail.com, moukengue@univ-douala.com,danlis1@yahoo.com
}

How to cite this paper: Inoussah, M.M., Adolphe, M.I. and Daniel, L. (2017) Assessment of Sustainability Indicators of Thermoelectric Power Generation in Cameroon Using Exergetic Analysis Tools. Energy and Power Engineering, 9, 22-39. http://dx.doi.org/10.4236/epe.2017.91003

Received: December 13, 2016

Accepted: January 19, 2017

Published: January 22, 2017

Copyright ( 92017 by authors and Scientific Research Publishing Inc. This work is licensed under the Creative Commons Attribution International License (CC BY 4.0).

http://creativecommons.org/licenses/by/4.0/

\section{(c) (i) Open Access}

\begin{abstract}
In this paper, we evaluate the performance and sustainability indicators of various thermal power generation technologies in Cameroon using the exergy analysis tools. For this purpose, on the basis of data from the International Energy Agency (IEA) for Cameroon corresponding to the period from 2006 to 2014, we calculated the average energy and exergy efficiencies of each electricity generation technology from thermal sources. The average values of the exergy efficiencies obtained are respectively $28.97 \%$ for the LFO plants, $30.94 \%$ for the HFO plants, $34.66 \%$ for the biofuel plants and $36.67 \%$ for the gas-fired plants. The average sustainability indexes for each of the technologies are determined and values range from 1.56 for LFO plants to 2.12 for biofuel plants. The improvement potentials of each technology are calculated in order to identify the tracks of increase of their efficiency. Average values range from 165.57 GWh for biofuel plants to 1301.77 GWh for LFO plants. The results of this study should enable the development of productive and applicable planning for future energy policies, in particular for the electricity sector in Cameroon.
\end{abstract}

\section{Keywords}

Exergy, Efficiency, Power Generation, Sustainability, Cameroon

\section{Introduction}

During the late twentieth century, the reflections of several authors have converged on one point. Thus, if the dynamics of growth observed during the latter part of this century continue, terrestrial ecosystems and even the world popula- 
tion will not be able to resist this high impact of human activity [1].

It must therefore be admitted that this growth is limited [2] [3]. It is with this in mind that measures have been taken to protect existing and future populations from the consequences of exceeding these limits.

Given this trend, specific terms and concepts have emerged in almost all sectors of activity, including, among others, economy, industry, construction and energy, electricity for example.

The notions of sustainable development [4] and integral sustainability [5] are the main terms distinguished in this new vocabulary. These two terms integrate purely environmental aspects and go even further.

As all human beings have the right to a healthy and productive life in harmony with nature [5], then social and economic factors, as well as ethical and cultural concerns, come into play.

Moreover, for any modern society to develop needs an energy system that ensures a constant supply. For this, it is necessary to have abundant resources, obtained at an affordable price and easy to transport.

These resources must also be of good quality. Better yet, to be suitable for conversion machines, they must have a high energy density.

It is important to remember that humanity in all its history has always used two crucial criteria in the choice of energy systems: technical availability and economic viability.

It is in recent decades that another criterion of this decision has been taken into account: the environmental impact that a system can have. This new factor is already playing a key role in assessing and comparing different sources of energy and technologies for a country's energy grid.

On the basis of these findings, we note that the need to control atmospheric emissions of greenhouse and other pollutant gases and substances will increasingly shed its light on the efficiency of all energy conversion processes and applications especially power generation, transmission, distribution, and final demand represented by existing consumption patterns and technologies. On the other hand, some of known energy sources have been nearly exhausted nowadays. Hence, issues related to economic costing and efficient utilization of all natural resources, including energy, gained vital importance. For these reasons, deep analysis and evaluation of periodical data for power generation and other final energy-consuming sectors are essential, and are considered as primary conditions to accomplish some of the national goals, which are designed to achieve sustainable development in all sectors of the economy. The present paper is among a series of practical articles, by authors, aimed to model various sectors and applications by employing insightful energy and exergy analysis [6] [7], considered first of its kind in Cameroon since there is no such study on energy and exergy use for the electric power sector. Thus, the objective of the present study is oriented towards determining exergy losses, related efficiencies and assessing sustainability indicators of the existent thermal technologies as first step of the choice of the future technologies of the Cameroonian electric 
system planning policies.

Since Cameroon is considering the implementation and updating of the national energy strategy by 2035, particular emphasis is placed on energy efficiency policies in various sectors, including the electricity generation sector. We believe that this study will provide scientific judgment and an overall view of the overall performance of thermal technologies for the production of electric power and be of use to engineers and scientists working in the field of electric power in Cameroon and in some countries neighboring country.

\section{An Overview of Electricity Generation in Cameroon}

Electrical Energy in Cameroon is produced from several sources through the various power plants [7] [8]. Production sources are of two types: Hydraulic source and thermal sources with a fossil fuel (Heavy fuel oil or HFO, Light fuel oil (diesel) or LFO, and Natural Gas) and biofuel (biomass and agricultural waste).

\subsection{Hydroelectric Dam Technology}

Cameroon has three hydroelectric dampower plants in its generation fleet as shown in Table 1. This hydro power plant is constructed in the Sanaga River (Edea and Song loulou) and Benoue River (Lagdo).

They are three storage regularization dams of the Sanaga River for a total of 7.6 billion cubic meters distributed as follows: Mbakaou (2.6 billion cubic meters), MAPE (3.2 billion cubic meters) and Bamendjin (1.8 billion cubic meters).

\subsection{Thermoelectric Technology}

Thermoelectricity is the phenomenon of combustion of a fuel (HFO, LFO, natural gas and biofuel and waste) in the presence of an oxidant (oxygen in the air) that puts the engine, which in its rotation causes a generator (alternator) thereby producing electricity [9] [10]. All thermal power plants encountered in Cameroon operate on this principle. The main thermal power plants of Cameroon and their characteristics are presented in Table 2.

The system's peak load in 2014 was 1346 MW (with $46.6 \%$ for thermal and 53.4\% for hydraulic), compared with 1167 MW in the previous year (2010). A growth rate is $13.3 \%$ and Figure 1 shows the share of each primary energy source in the electricity generation in Cameroon in 2014. We can clearly see that thermals sources represent about $27 \%$ of electricity generation in 2014 .

\section{Methods}

\subsection{Power Engine Modelling}

An Engine is a device which converts one form of energy to another form of energy. Normally most of the engines convert thermal to mechanical energy known as heat engines [9] [10]. It is a device which transforms chemical energy of fuel to thermal energy and utilizes this thermal energy to perform useful work (mechanical, electricity...). 
Table 1. Main hydroelectric power stations in Cameroon.

\begin{tabular}{ccccc}
\hline Power station & $\begin{array}{c}\text { Installed } \\
\text { capacity }(\mathrm{MW})\end{array}$ & Flow rate $\left(\mathrm{m}^{3} / \mathrm{h}\right)$ & Drop height $(\mathrm{m})$ & River \\
\hline Edea I, II \& II & 263 & 1250 & 24 & Sanaga \\
Song loulou & 384 & 1040 & 42 & Sanaga \\
Lagdo & 72 & 436 & 20 & Benoue \\
\hline
\end{tabular}

Table 2. Main thermal power stations in Cameroon.

\begin{tabular}{ccc}
\hline Power station & Installed capacity & Type of fuel \\
\hline Bassa II \& III & 18.6 & LFO \\
Bafoussam & 14.3 & LFO \\
Logbaba I \& II & 17.6 & LFO/HFO \\
Oyomabang I \& II & 32.3 & HFO/LFO \\
Limbe & 85 & HFO \\
Yassa-Dibamba (DPDC) & 86.1 & HFO \\
Kribi (KPDC) & 216 & Gas \\
The isolated Power stations & 157 & LFO
\end{tabular}

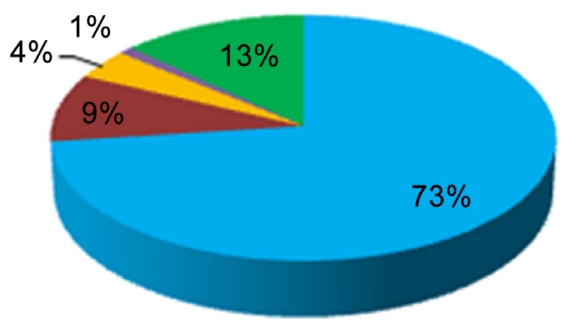

\footnotetext{
Hydro power plants

EFO power plants

HFO power plants

Biofuel power plants

- Gas power plants
}

Figure 1. Share of the electricity generation by sources of primary energy in Cameroon (2014).

Heat engines are classified into two types based on the combustion chamber. They are:

-Internal Combustion Engine;

-External Combustion Engine.

Therefore the characteristics of the fuels play a vital role on the performance characteristics. Fuels are basically of two types:

-Conventional fuels: Conventional fuels include: fossil fuels (petroleum (oil), coal, propane, and natural gas). Basically, conventional fuels are classified into three types: Solid fuels, Gaseous fuels, Liquid fuels;

-Non-conventional fuels: Some well-known alternative fuels include bio-diesel, bio-alcohol (methanol, ethanol and butanol), chemically stored electricity (batteries and fuel cells), hydrogen, non-fossil methane, non-fossil natural gas, vegetable oil, and other biomass sources.

To utilize the energy of fuel in most usable form, it is required to transform the fuel from one state to another, i.e. from solid to liquid or gaseous state, liquid 
to gaseous state, or from its chemical energy to some other form of energy via single or many stages. In this way, the energy of fuels can be utilized more effectively and efficiently for various purposes.

\subsubsection{Modelling Diesel Engine for Electricity Generation}

Diesel engine is an internal combustion engine in which the combustion of a fuel (normally a fossil fuel) occurs with an oxidizer (usually air) in a combustion chamber that is an integral part of the working fluid flow circuit. In an internal combustion engine (ICE) the expansion of the high-temperature and high-pressure gases produced by combustion apply direct force to some component of the engine [9] [10].

To generate electric power, it is essential to turn the rotor of an alternator by means of a prime mover. The prime mover can be driven by different methods. Using diesel engine as prime mover is one of the popular methods of generating power. When prime mover of the alternators is diesel engine, the power station is called diesel power station. The mechanical power required to drive alternator comes from the combustion of diesel.

The diagram in Figure 2 shows the simplify process of generating electricity Diesel power plants

\subsubsection{Modelling Steam Engines for Electricity Generation}

Steam engine is a heat engine where an internal working fluid is heated by combustion in an external source, through the engine wall or a heat exchanger [9] [10].

Electrical energy generation using steam turbines involves three energy conversions, extracting thermal energy from the fuel and using it to raise steam, converting the thermal energy of the steam into kinetic energy in the turbine and using a rotary generator to convert the turbine's mechanical energy into electrical energy.

In this kind of plants, steam is raised by burning fuel, like coal, oil or gas in a

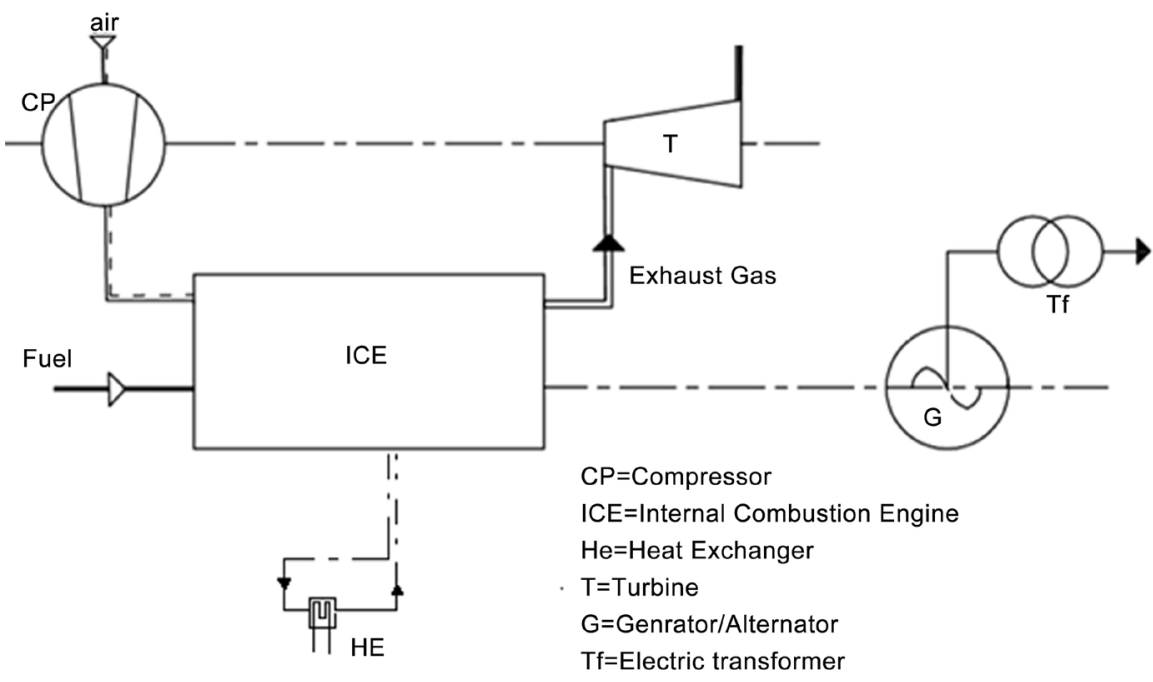

Figure 2. Simplified schematic diagram of a diesel engine [9] [10]. 
combustion chamber. Recently these fuels have been supplemented by limited amounts of renewable biofuels and agricultural waste.

The chemical process of burning the fuel releases heat by the chemical transformation (oxidation) of the fuel. This can never be perfect. There will be losses due to impurities in the fuel, incomplete combustion and heat and pressure losses in the combustion chamber and boiler. Typically these losses would amount to about $10 \%$ of the available energy in the fuel. The diagram in Figure 3 shows the simplify process of generating electricity in steam power plants.

\subsection{Exergy Calculation}

By describing the use of energy resources in society in terms of exergy, important knowledge and understanding can be gained, and areas can be identified where large improvements could be obtained by applying efficient technology in the sense of more efficient energy-resource conversions. In principle, the exergy matter can be determined by bringing it to the dead state by means of reversible processes [11] [12]. The basic equations used in exergy analysis modelling for this study are given below.

\subsubsection{Chemical Exergy of Fuel}

The specific exergy of the fuel at environmental conditions reduces to chemical exergy, can be written as:

$$
\varepsilon_{f}=\gamma_{f} \cdot \operatorname{LHV}_{f}
$$

where $\varepsilon_{f}$ is the fuel specific exergy, $\gamma_{f}$ the exergy grade function, and $\mathrm{LHV}_{f}$ the lower heating value of the fuel.

The exergy grade function for various types of fuel is calculated based on the chemical composition of the fuel as follows [13] [14] [15]:

For fuel oil (LFH and HFO) and biofuel:

Essential constituents of the fuel oil are carbon, hydrogen, oxygen, sulfur and nitrogen, with the respective weight percentages $c, h, o, s$ and $n$.

The general formula of liquid biofuels is: $\mathrm{C}_{\mathrm{x}} \mathrm{H}_{\mathrm{y}} \mathrm{O}_{z}$. The exergy associated quality factor is calculated with the same relationship as for fuel

$$
\gamma_{f}=\left[1.0401+0.1728 \frac{h}{c}+0.0432 \frac{o}{c}+0.2169 \frac{s}{c} \cdot\left(1-2.0628 \frac{h}{c}\right)\right]
$$

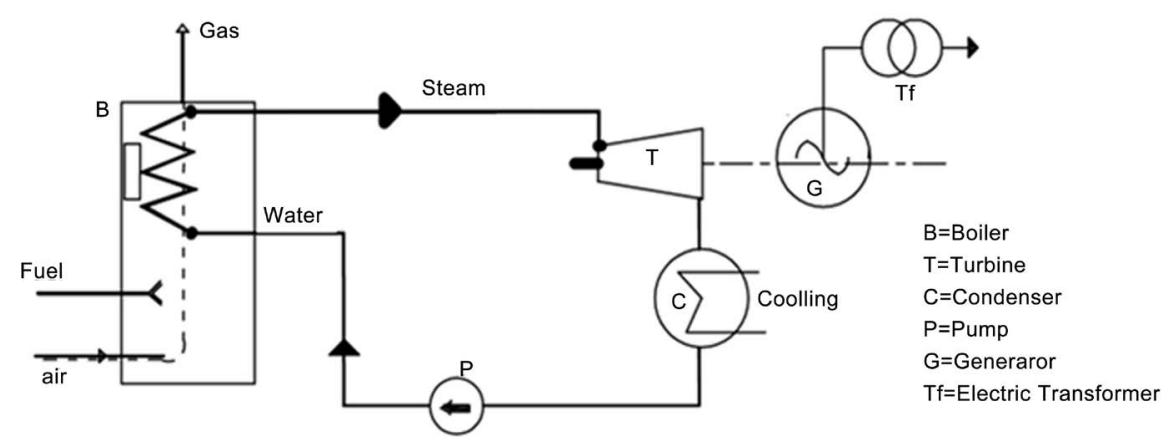

Figure 3. Simplified schematic diagram of a steam plant [9] [10]. 
For natural gas:

Natural gas contains mostly methane $\left(\mathrm{CH}_{4}\right)$ with a percentage of over $95 \%$.

$$
\gamma_{f}=\left[1.033+0.0169\left(\frac{b}{a}\right)-\frac{0.0698}{a}\right]
$$

where $a$ and $b$ represent the number of atoms of carbon and hydrogen in the gaseous fuel.

Table 3 shows higher heating value, fuel exergy grade function, and chemical exergy of different fuels considered in this study [13] [14] [15]. As shown, in Table 3, all values of the exergy grade function are very close to unity. Consequently, the common practice in such cases is to assume that the exergy of the fuel is approximately equal to the higher heating value.

\subsubsection{Exergy Transfer with Work Interaction and Electricity}

From the definition of exergy, electricity, $W_{e}$, is identical to the physical work exergy, $E^{W_{e}}$ :

$$
E^{W_{e}}=W_{e}
$$

\subsubsection{Exergy Transfer with Heat Interaction}

The exergy transfer rate $\left(E_{x_{h}}\right)$ connected with the heat transfer rate $\left(Q_{i}\right)$ can be calculated by Equation (5) [13] [16]:

$$
E^{Q}=\int_{A}\left(\frac{T-T_{0}}{T}\right) Q_{i} \mathrm{~d} A
$$

where $A$ is the heat transfer area, $T_{0}$ is the temperature of the environment, $T$ is the temperature at which the heat transfer takes places. When there is a uniform temperature distribution,

$$
\int_{A} Q_{i} \mathrm{~d} A=Q_{A}
$$

And Equation (6) becomes:

$$
E^{Q}=\left(1-\frac{T_{0}}{T}\right) Q_{A}
$$

\subsubsection{Physical Exergy Associated with Material Streams}

Physical exergy is the work obtainable by taking the substance through reversible processes from its initial state temperature $T$ and pressure $P$, to the state determined by the temperature $T_{0}$ and the pressure $P_{0}$ of the environment. It can be calculated with:

Table 3. Higher heating value, exergy grade function, and chemical exergy for different fuels (at $25^{\circ} \mathrm{C}$ and $1 \mathrm{~atm}$ ).

\begin{tabular}{cccc}
\hline Fuel & LHV $(\mathrm{kJ} / \mathrm{kg})$ & $\gamma_{f}$ & $\varepsilon_{f} \quad(\mathrm{~kJ} / \mathrm{kg})$ \\
\hline LFO & 42,800 & 1.07 & 45,796 \\
HFO & 41,640 & 1.06 & 43,036 \\
Biofuel & 39,760 & 1.10 & 43,736 \\
Natural Gas & 50,000 & 1.02 & 49,000 \\
\hline
\end{tabular}




$$
\dot{E}_{p h}=H-H_{0}-T_{0}\left(S-S_{0}\right)
$$

where $H$ is the enthalpy and $S$ the entropy. The physical exergy can be expressed into a thermal and a pressure component, also called mechanical component.

By using the perfect gas laws in [13] [16] and assuming a constant specific isobaric heat capacity $(\mathrm{Cp})$ follows:

$$
e_{p h}=C_{p}\left\{\left(T-T_{0}\right)-T_{0} \ln \left(\frac{T}{T_{0}}\right)\right\}+R T_{0} \ln \left(\frac{P}{P_{0}}\right)
$$

For solids and liquids Equation (9) assuming a constant specific heat (c) becomes:

$$
e_{p h}=C\left\{\left(T-T_{0}\right)-T_{0} \ln \left(\frac{T}{T_{0}}\right)\right\}+v_{m}\left(P-P_{0}\right)
$$

where $v_{m}$ is the specific volume, determined at temperature $T_{0}$.

\subsubsection{Irreversibility}

The irreversibility, also called exergy destruction or exergy loss, is calculated by setting up the exergy balance and taken the difference between all incoming and outgoing exergy flows as stated in Equation (11):

$$
I=\sum_{\text {in }} E_{i}-\sum_{\text {out }} E_{j}
$$

Another way of calculating the irreversibility can be done by the Gouy-Stodola equation [17] [18] in which the entropy increase is multiplied by the environmental temperature, as in Equation 12:

$$
I=T_{0}\left(\sum_{\text {in }} S_{i}-\sum_{\text {out }} S_{j}\right)=T_{0} \Delta S
$$

\subsection{Balance Equation and Indicators Relations}

In this part, we perform the exergy analysis based on a systemic approach. In this analysis, we will determine the irreversibilities and the exergy efficiency of the system. Given the complexity of this analysis, we will model our system as a black box, characterized by inputs and outputs. At the entrance, we will have the incoming exergy, and at the exit, the outgoing exergy of the system. The losses induced by the system are: the internal destruction of the exergy and the rejection of the exergy. The outgoing exergy is composed of useful exergy and rejected exergy.

For the rest of calculations concerning these thermal power plants, we will use the modelling in Figure 4 [19].

\subsubsection{Mass, Energy and Exergy Balance}

An exergetic analysis involves mass, energy and exergy balances for all plant components (control volumes), and definition of exergetic efficiency for each of them. The following equations represent the mass, energy and exergy balances in the control volumes. Kinetic and potential energy/exergy are not considered [20].

The mass balance equation can be expressed in the rate form as: 


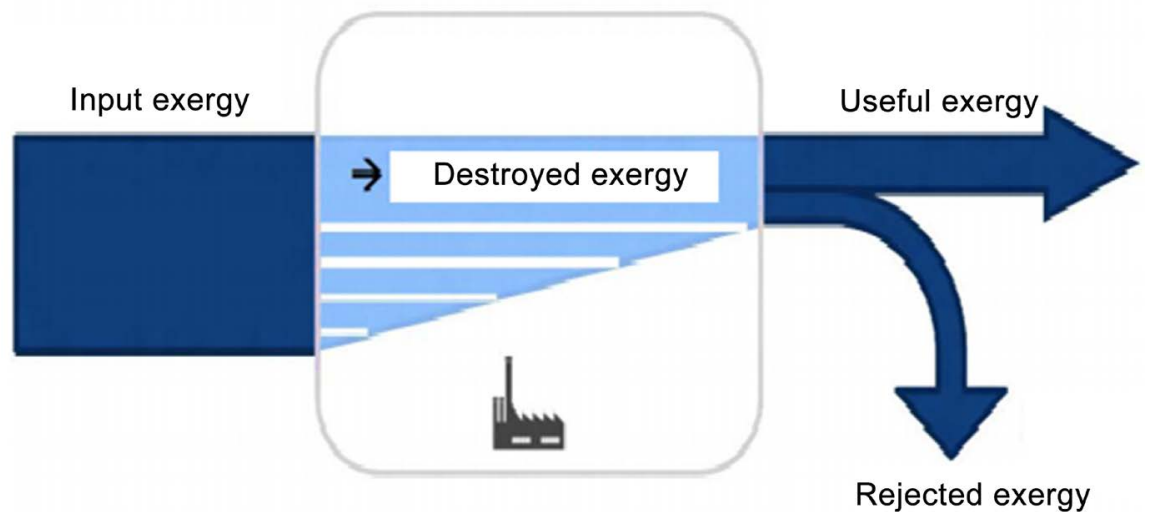

Figure 4. Modelling of the system [19].

$$
\sum \dot{m}_{\text {in }}=\sum \dot{m}_{\text {out }}
$$

where $\dot{m}$ is the mass flow rate, and the subscript index in stands for inlet and out for outlet.

The general energy balance can be expressed below as the total energy inputs equal to total energy outputs.

$$
\sum E_{\text {in }}=\sum E_{\text {out }}
$$

The general exergy balance can be written as follows:

$$
\sum E_{x_{\text {in }}}-\sum E_{x_{\text {out }}}=\sum E_{x_{\text {dest }}}
$$

where $E$ and $E_{x}$ represent respectively the energy en the exergy. The subscript index dest stands for destroyed.

\subsubsection{Energy and Exergy Efficiencies}

Energy efficiency (first law efficiency) is the ratio of energy contained in useful products of a process to energy contained in all input streams, while exergy efficiency (second law efficiency) is the ratio of exergy contained in the useful product to the exergy contained in all input streams. Energy efficiency $(\eta)$ and exergy efficiency $(\psi)$ are defined as:

$$
\begin{aligned}
\eta & =\frac{\text { Energy in products }}{\text { Total energy input }} \times 100 \% \\
\psi & =\frac{\text { Exergy in products }}{\text { Total exergy input }} \times 100 \%
\end{aligned}
$$

Energy $\eta_{e}$ and exergy $\psi_{e}$ efficiencies for electricity generation through fossil fuels or biofuel for the mass $m_{f}$ can be expressed as follow:

$$
\begin{gathered}
\eta_{e}=\frac{W_{e}}{m_{f} \mathrm{LHV}_{f}} \times 100 \% \\
\psi_{e}=\frac{E^{W_{e}}}{m_{f} \varepsilon_{f}} \times 100 \%=\frac{W_{e}}{m_{f} \gamma_{f} \mathrm{LHV}_{f}} \times 100 \%=\frac{\eta_{e}}{\gamma_{f}}
\end{gathered}
$$

Therefore, exergy efficiency for electricity generation process can be taken as equivalent to the corresponding energy efficiency [21]. 


\subsubsection{Sustainability Index and Improvement Potential of Exergy}

Sustainable development requires not only that the sustainable supply of clean and affordable energy resources be used, but also the resources should be used efficiently.

Exergy methods are very useful tools for improving efficiency, which maximize the benefits and usage of resources and also minimize the undesired effects (such as environmental damage) [22]. Exergy analysis can be used to improve the efficiency and sustainability [23].

The relationship between exergy efficiency $(\psi)$ and the sustainability index $(S I)$, as given in [22] [24], is modified here for this application:

$$
\psi=1-\frac{1}{S I}
$$

where

$$
S I=\frac{1}{D_{p}}
$$

Here, $D_{p}$ is the depletion factor defined as the ratio of exergy destruction rate to the input exergy rate of the system can be given as [25],

$$
D_{p}=\frac{\text { Destroyed exergy }}{\text { Input exergy }}
$$

The maximum improvement in the exergy efficiency for a process or system is obviously achieved when the exergy loss or irreversibility $\dot{E}_{x_{\text {in }}}-\dot{E}_{x_{\text {out }}}$ is minimized [26]. Consequently, he suggested that it is useful to employ the concept of an exergetic "improvement potential" when analyzing different processes or sectors of the economy. This improvement potential in the rate form, denoted $I \dot{P}$, is given by Equation (23):

$$
I \dot{P}=(1-\psi)\left(\dot{E}_{x_{\text {in }}}-\dot{E}_{x_{\text {out }}}\right)
$$

\subsection{Methodology and Data Sources}

In order to evaluate the energetic and exergetic performances of thermal power generation systems in Cameroon, we used data from the International Energy Agency (IEA) [27]. The reliability of these data was verified and validated on the basis of the reports of the national structures and more precisely the report of the Ministry of Water and Energy of Cameroon of 2014 (MINEE) [8], the operating data of the Kribi Power Development Company (KPDC) [28] and the Dibamba Power Development Company (DPDC) [29], the 2011 Cameroon Energy Information System (SIE-Cameroon) report, and the 2013 National Institute of Statistics Cameroon) [30].

The International Energy Agency provides data on primary energy consumption by source as well as electricity production data from each of these sources. It should be noted that the primary sources used in Cameroon are light fuel or diesel, fuel oil, natural gas for fossil sources and biofuels (agro-industrial residues, wood waste ...) for renewable sources. 
Table 4 and Table 5 show the evolution of primary energy consumption by source (Table 4) and the evolution of electricity production by source (Table 5) our balance sheets (energy, energy and mass) are based on these data and the results obtained will be used to evaluate the evolution of the performance indicators (energy and energy efficiency) and the sustainability index.

\section{Results and Discussion}

As presented at the beginning of this work, electric power in Cameroon is produced mainly from hydraulic resources, and production is supplemented by medium-sized thermal power plants using fossil resources (LFO, HFO or Natural Gas) and Also renewable resources (biofuel) which is still currently weakly developed and generally used in the agro industrial sector. The diagram in Figure 5 illustrates in a simplified way the production of electricity in Cameroon.

The results of the analysis of the performance and durability of thermal technologies for the production of electricity are presented in this section

From the data on primary energy consumption and electricity generation, we have computed the input and output exergies for each technology for the period 2006 to 2014. The energy and exergy efficiencies are also evaluated and the curves illustrating the evolutions of the various quantities are plotted.

\subsection{Balance Analysis}

The exergy balance in Figure 6 shows that each conversion system makes it possible to obtain four forms of exergy, namely: the input exergy supplied by the fuel, the useful exergy in the formof electricity, the loss of exergy in the exhaust gas and the loss of exergy due to irreversibilities. We evaluated the annual exergy

Table 4. Primary energy consumption for thermoelectricity generation in Cameroon from 2006 to 2014 .

\begin{tabular}{cccccccccc}
\hline $\begin{array}{c}\text { Primary energy } \\
\text { consumption } \\
\text { (ktoe) }\end{array}$ & 2006 & 2007 & 2008 & 2009 & 2010 & 2011 & 2012 & 2013 & 2014 \\
\hline LFO & 101 & 129 & 169 & 241 & 265 & 270 & 280 & 294 & 163 \\
HFO & 35 & 61 & 39 & 54 & 58 & 60 & 63 & 69 & 70 \\
Biofuel & 145 & 17 & 17 & 16 & 13 & 14 & 14 & 15 & 16 \\
Natural Gas & 0 & 482 & 500 & 413 & 417 & 298 & 358 & 617 & 896 \\
\hline
\end{tabular}

Table 5. Electricity generation in Cameroon by thermal power plant from 2006 to 2014.

\begin{tabular}{cccccccccc}
\hline $\begin{array}{c}\text { Electricity } \\
\text { generation by } \\
\text { sources (GWh) }\end{array}$ & 2006 & 2007 & 2008 & 2009 & 2010 & 2011 & 2012 & 2013 & 2014 \\
\hline LFO & 426 & 571 & 661 & 1048 & 953 & 970 & 1014 & 1060 & 620 \\
HFO & 145 & 267 & 151 & 235 & 210 & 217 & 228 & 249 & 266 \\
Biofuel & 643 & 76 & 77 & 71 & 59 & 61 & 64 & 68 & 896 \\
Natural Gas & 0 & 482 & 500 & 413 & 417 & 298 & 358 & 617 & 896 \\
\hline
\end{tabular}




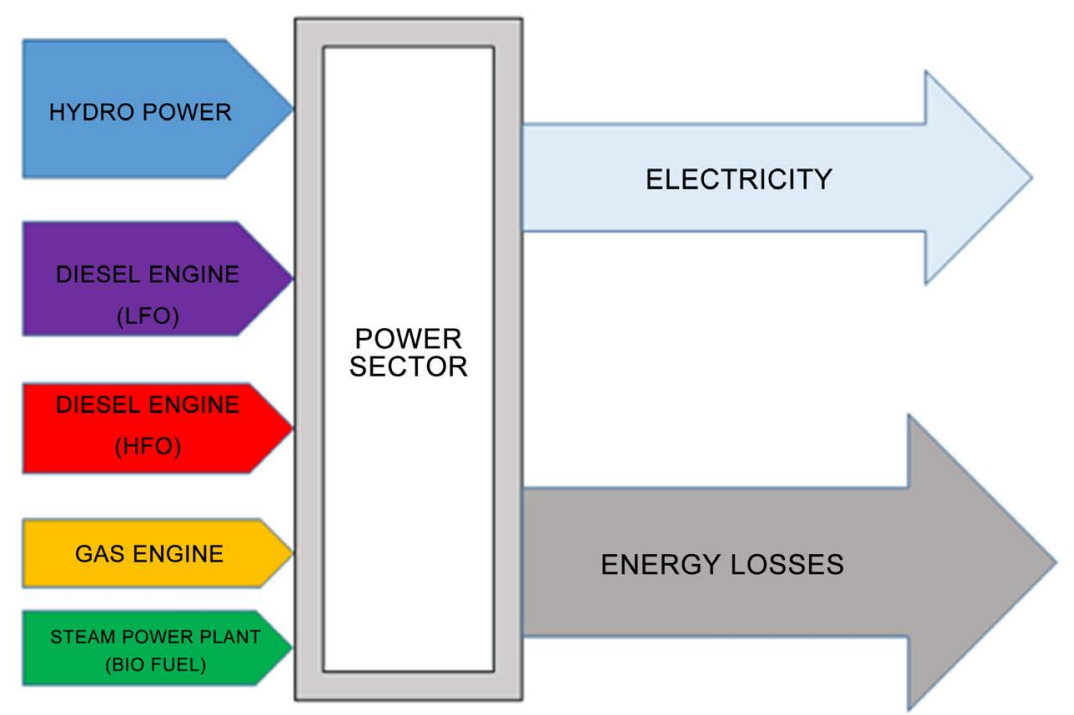

Figure 5. An illustrative presentation of electricity production in Cameroon.

from the expressions of these different forms of exergy. The figure below shows the evolution from 2006 to 2014 of these quantities for each mode of conversion of the primary exergy (LFO thermal power plants to, HFO thermal power plants, biofuel thermal plants and natural gas thermal power plants).

The average exergy balance over the 9-year study period gives the results illustrated below.

We see through Figure 7 that the exergy destroyed because of the irreversibilities is very high, representing for each technology about $50 \%$ of the incoming primary exergy (exergy of the fuel). It is higher for thermal power plants at the LFO (62\%) using the Diesel cycle in an internal combustion engine and somewhat lower for the biofuel thermal power plants with the Rankine cycle in an external combustion engines.

\subsection{Analysis of Performance Indicators}

The energy and exergy yields of each mode of electricity production were determined. Averages over the entire observation period are calculated. It is very clear in Figure 8 that for each of these production technologies, the energy efficiency is higher than the exergy efficiency, thus reflecting the importance of irreversibilities on the degradation of primary energy.

On the other hand, we note that irreversibilities are less important for gasfired thermal technologies and more pronounced for thermal biomass technologies. This can be explained by the modernity of gas-fired thermal technologies and also by the quality of the primary fuel (the natural gas characteristics are more or less constant, which is not the case for biomass). Table 6 shows the relative fraction of degradation of primary energy due to irreversibilities for different technologies.

By analyzing the difference between the energy efficiency and the exergy efficiency of each electricity generation technology, the quality of conversion of 

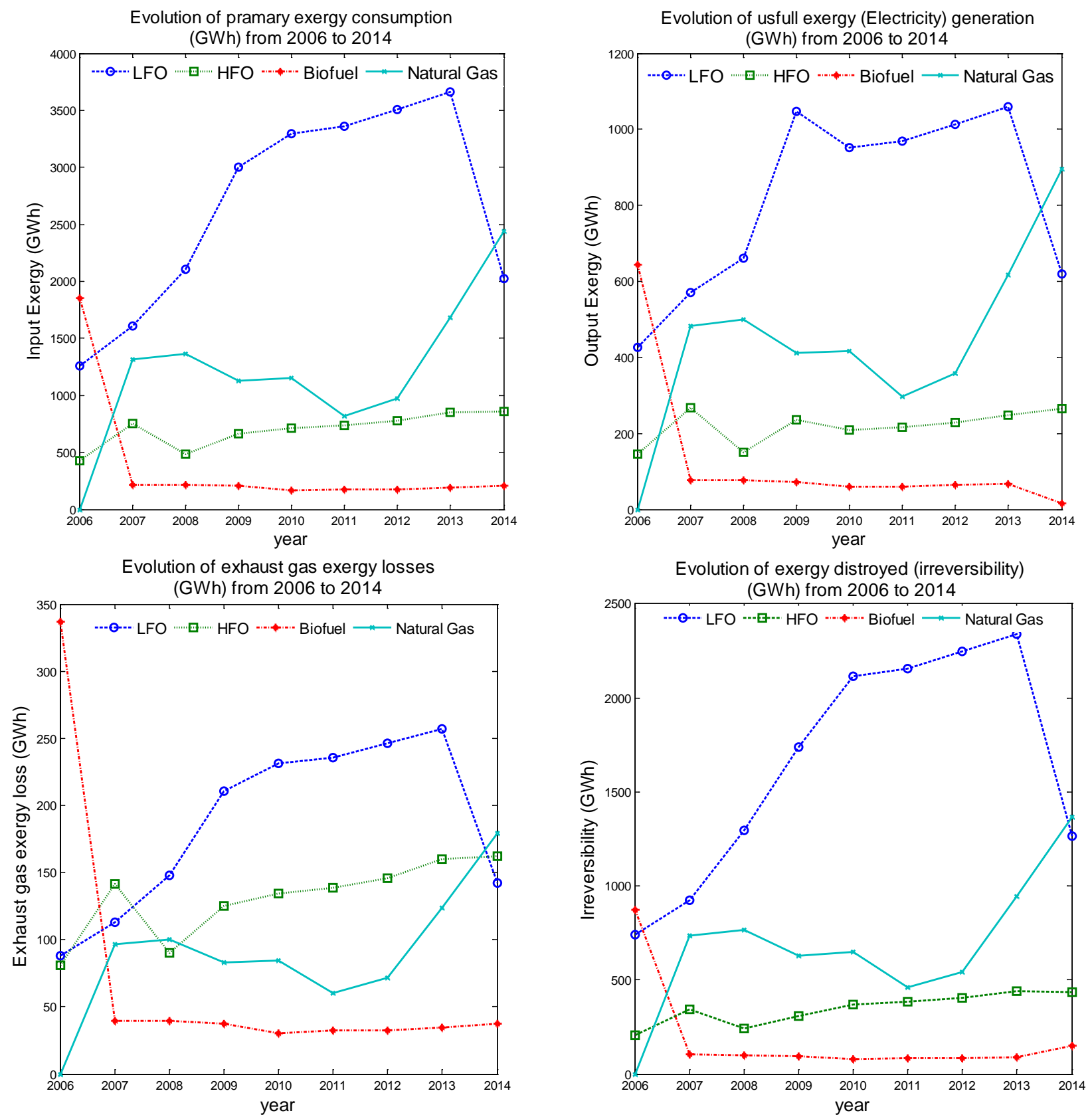

Figure 6. Exergy balance for different conversion technologies: evolution from 2006 to 2014.

primary energy is better in gas-fired power plants (1.96\%) and very poor in power stations Thermal fuels $(9.09 \%)$

\subsection{Analysis of Sustainability Indicators}

Figure 9 shows the average sustainability indexes of different electricity generation technologies in Cameroon. The sustainability index for biofuel units (renewable) is higher (2.12), followed by units at LFO (1.95), then natural gas units (1.79), and units at HFO (1.56). A high sustainability index reflects a better sustainability of the technology. However, given the characteristics of natural gas, one would have expected a high durability index. Its relative low value is due to 


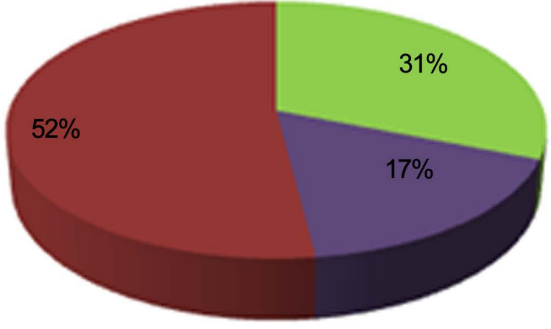

(a) LFO power plants

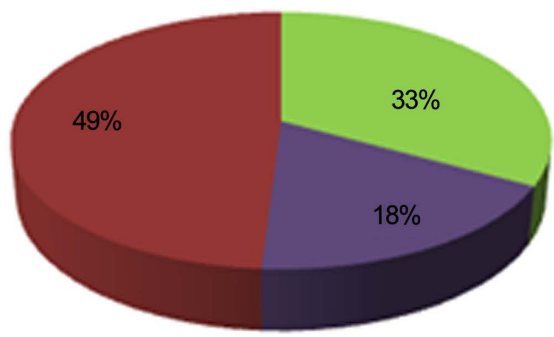

(c) Biofuel power plants

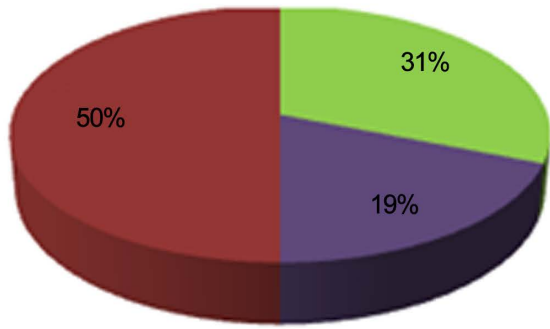

(b) HFO power plants

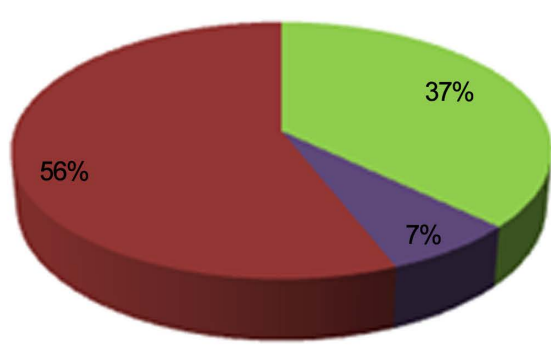

(d) GAS power plants
$=$ Useful exergy

Exhaust gas exergy

n Desroyed exergy

Figure 7. Share of exergy forms in the average exergy balance by conversion technology.

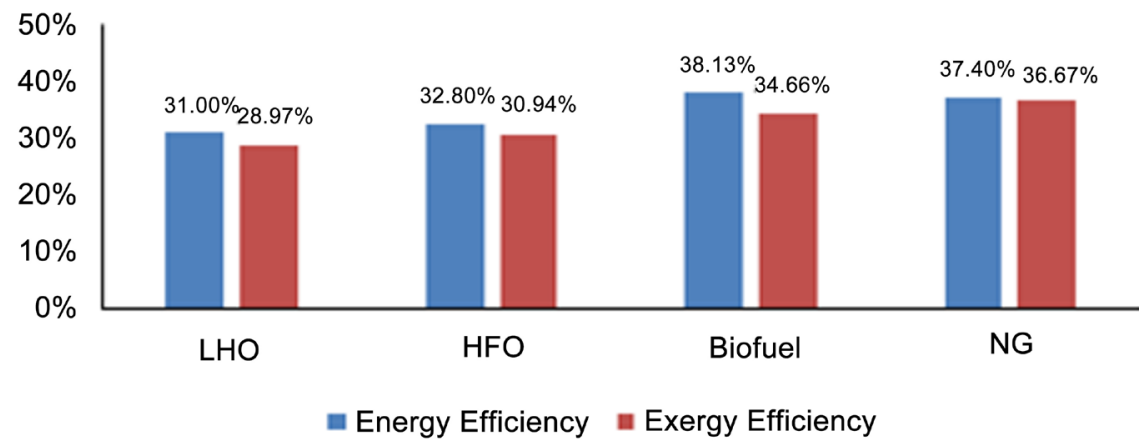

Figure 8. Average energy and exergy efficiency of different conversion technologies.

Table 6. Average relative fraction of exergy destroyed for different conversion technology.

\begin{tabular}{cccc}
\hline Fuel & Energy efficiency (\%) & Exergy efficiency (\%) & $\begin{array}{c}\text { Relative fraction of } \\
\text { exergy destroyed (\%) }\end{array}$ \\
\hline LFO & 31.00 & 28.97 & 6.54 \\
HFO & 32.80 & 30.94 & 5.66 \\
Biofuel & 38.13 & 34.66 & 9.09 \\
Natural Gas & 37.40 & 36.67 & 1.96 \\
\hline
\end{tabular}

the maltreatment of natural gas, the management of water supplies since this technology has just been introduced into the production mix of Cameroon and the workforce is not yet sufficiently qualified. 


\subsection{Analysis of the Improvement Potential of Conversion Technologies}

The last indicator in this study is the improvement potential. For each of the four technologies in our study, we evaluated the improvement potential for the exergy efficiency. The calculation results are shown in Figure 10. We can see that the LFO plants have a very high potential for improvement corresponding to the low efficiency. Thus a good maintenance policy and also actions to improve the performance of the operators involved in these energy conversion machines could contribute to increase the exergetic efficiency of these production units, hence ensuring sustainable production and Preservation of fossil and natural resources.

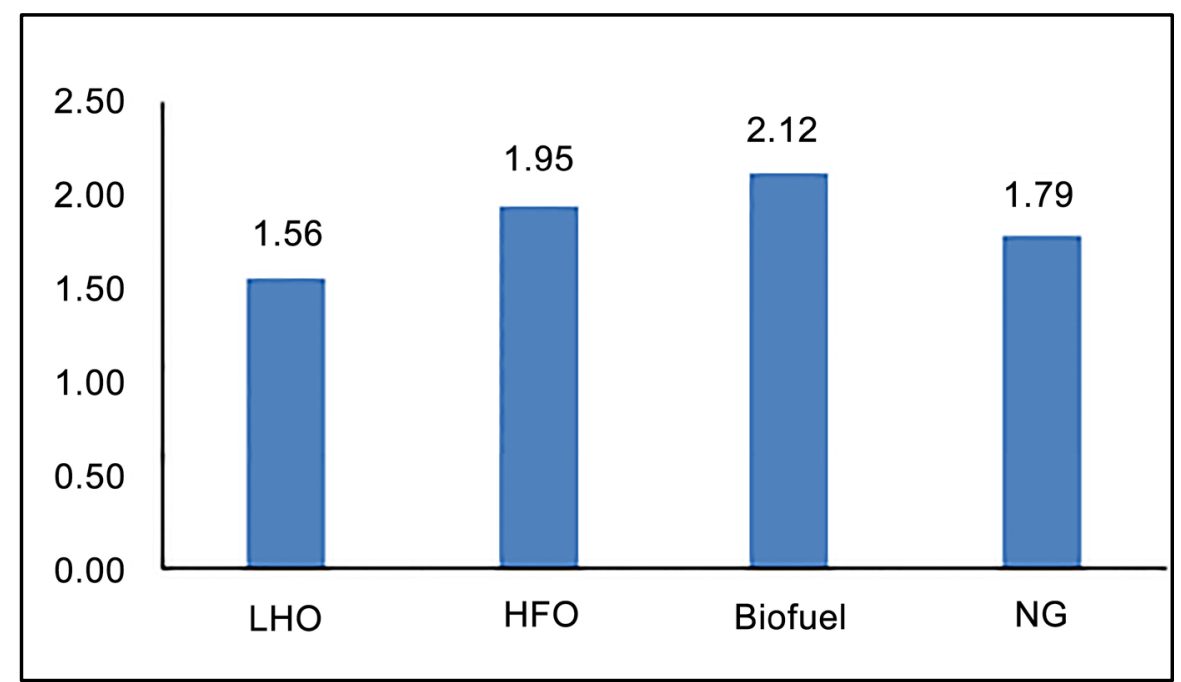

Figure 9. Average sustainability index values of various electricity generation technologies.

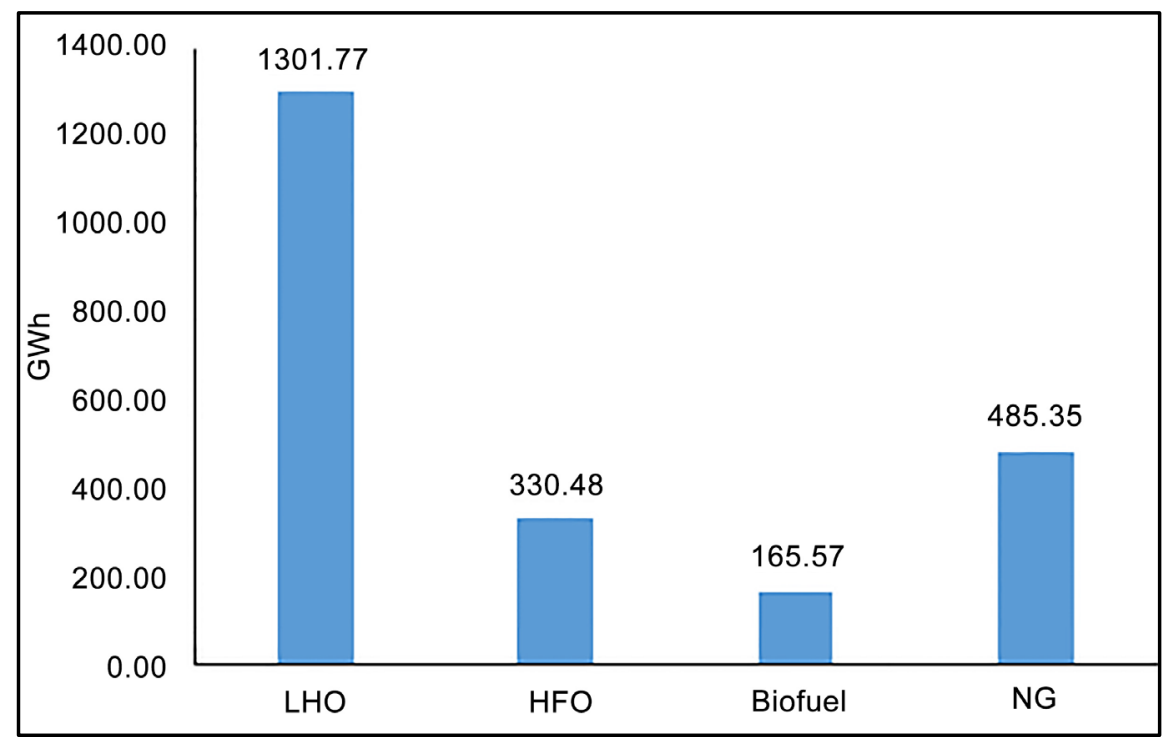

Figure 10. Average improvement potential values of various electricity generation technologies. 


\section{Conclusions}

In this paper, we have used the International Energy Agency (IEA) statistical data on electric power generation in Cameroon to evaluate the technical performance indicators as well as the indicators of sustainability of the different thermal technologies of production of electricity. The methodological tools for exergy analysis were used for these evaluations. The calculation of the exergy performances of the different installations reflects the standard values of each technology, although they are slightly low. The values of the sustainability indexes found give a classification of the technologies in terms of preservation and efficient use of the primary resources. The potential for improvement assessed for each of the technologies also shows that there is an opportunity to increase the efficiencies of existing facilities.

This study can be exploited as a tool for decision-making by those involved in the development of the electricity sector in Cameroon and some neighboring countries.

\section{References}

[1] Bouvier, L.F. and Grant, L. (1994) How Many Americans? Population, Immigration and the Environment. Sierra Club Books, San Francisco, CA, USA.

[2] Meadows, D., Meadows, D. and Randers, J. (2004) Limits to Growth: the 30-Year Update. 3rd Edition, Chelsea Green Publishingng, White River Jct., VT, USA.

[3] Barros, J.J.C., et al. (2015) Assessing the Global Sustainability of Different Electricity Generation Systems. Energy, 89, 473e-489e. http://www.elsevier.com/locate/energy https://doi.org/10.1016/j.energy.2015.05.110

[4] United Nations (1987) Our Common Future. World Commission on Environment and Development. Oxford University Press, Oxford, UK.

[5] United Nations (1992) The Rio Declaration on Environment and Development [Internet]. The United Nations Conference on Environment and Development (UNCED), Rio of Janeiro, Brazil, 3-14 June 1992. http://www.un.org/documents/ga/conf151/aconf15126-1annex1.htm

[6] ARSEL (2014) Politique Nationale, Stratégie et Plan d'Action pour l'Efficacité Energétique dans le secteur de l'électricité au Cameroun Rapport final-Mars 2014. Agence de régulation du Secteur de l'Electricité-Cameroun.

[7] SIE-Cameroun (2011) Situation Energétique du Cameroun: Rapport 2011, Système d'Information Energétique du Cameroun. Ministère de L'eau et de L'énergie, Yaoundé.

[8] MINEE (2014) Statistical Yearbook of Cameroon's Water and Energy. Collection of Series of Water and Energy Sub-Sector Statistical Information up to 2013. Ministère de l'Eau et de l'Energie, Yaoundé.

[9] Sarlos, G., Haldi, P.A. and Verttraete, P. (2002) Système énergétiques-Offre et demande d'énergie: Méthodes d'analyse. Vol. 21, Traité de génie civil de l'EPFL, Presses Polytechniques et Universitaires Romande.

[10] Joseph, M. and Wauters, P. (2011) Installations thermique motrices: Analyse énergétique et exergétique. 2nd Edition, UCL-Presses Universitaires de Louvain.

[11] Cornelissen, R.L. (1997) Thermodynamics and Sustainable Development. The Use of Exergy Analysis and the Reduction of Irreversibility. PhD Thesis, Universiteit Twente, Twente. 
[12] Koumi, N.S., Ayina Ohandja, L.M., Kemajou A. and Monkam, L. (2014) Design and Simulation of Hybrid Solar High-Temperature Hydrogen Production System Using both Solar Photovoltaic and Thermal Energy. Sustainable Energy Technologies and Assessments, 7, 279-293. http://www.elsevier.com/locate/seta https://doi.org/10.1016/j.seta.2014.05.002

[13] Szargut, J., Morris, D. and Steward, R. (1988) Exergy Analysis of Thermal, Chemical, and Metallurgical Processes. Hemisphere Publishing Corporation, New York.

[14] Reistad, G. (1975) Available Energy Conversion and Utilization in the United States. Journal of Energy Power, 97, 429-434. https://doi.org/10.1115/1.3446026

[15] Petchers, N. (2003) Combined Heating, Cooling and Power Handbook: Technologies and Application. The Fairmont Press, Lilburn.

[16] Kotas, T.J. (1995) The Exergy Method of Thermal Plant Analysis. 2nd Edition, Krieger Publishing, Malabar, 318 p.

[17] Umberto, L. (2013) Entropy and Exergy in Irreversible Renewable Energy Systems. Renewable and Sustainable Energy Reviews, 20, 559-564. https://doi.org/10.1016/j.rser.2012.12.017

[18] Gouy, G. (1889) Sur l'énergie utilisable. Journal de Physique, 8, 501-518. https://doi.org/10.1051/jphystap:018890080050101

[19] Enea Consulting (2013) L'Exergie Concept. Enjeux et Usages pour l'Industrie, 16 p.

[20] Hepbasli, A. (2008) A Key Review on Exergetic Analysis and Assessment of Renewable Energy Resources for a Sustainable Future. Renewable and Sustainable Energy Reviews, 12, 593-661. http://www.elsevier.com/locate/rser https://doi.org/10.1016/j.rser.2006.10.001

[21] Dincer, I., Hussain, M.M. and Al-Zaharnah, I. (2004) Analysis of Sectoral Energy and Exergy Use of Saudi Arabia. International Journal of Energy Research, 28, 205-243. https://doi.org/10.1002/er.962

[22] Balta, M.T., Hepbasli, A. and Dincer, I. (2010) Thermodynamic Performance Comparison of Some Renewable and Non-Renewable Hydrogen Production Processes.

[23] Naterer, G.F., Gabriel, K., Wang, Z.L., Daggupati, V.L. and Gravelsins, R. (2008) Thermochemical Hydrogen Production with a Copper-Chlorine Cycle. I. Oxygen Release from Copper Oxychloride Decomposition. International Journal of Hydrogen Energy, 33, 5439-5450. https://doi.org/10.1016/j.ijhydene.2008.05.035

[24] Rosen, M.A., Dincer, I. and Kanoglu, M. (2008) Role of Exergy in Increasing Efficiency and Sustainability and Reducing Environmental Impact. Energy Policy, 36, 128-137. https://doi.org/10.1016/j.enpol.2007.09.006

[25] Connelly, L. and Koshland, C.P. (1997) Two Aspects of Consumption: Using an Exergy-Based Measure of Degradation to Advance the Theory and Implementation of Industrial Ecology. Resources, Conservation and Recycling, 19, 199-217. https://doi.org/10.1016/S0921-3449(96)01180-9

[26] Van Gool, W. (1997) Energy Policy: Fairlytales and Factualities. In: Soares, O.D.D., Martins da Cruz, A., Costa Pereira, G., Soares, I. and Reis, A., Eds., Innovation and Technology-Strategies and Policies, Kluwer, Dordrecht, 93-105. https://doi.org/10.1007/978-0-585-29606-7_6

[27] IEA Statistics (2006-2014) International Energy Agencestatistical Data Base. Energy Statistic Division. https://www.iea.org/statistics/statisticssearch/report/?country=Cameroon

[28] KPDC (2015) Rapport d'activité 2014. Kribi Power Development Company, Kribi.

[29] DPDC (2015) Rapport d'activité 2014. Dibamba Power Development Company, 
Dibamba.

[30] INS (2013) Annuaire Statistique du Cameroun. Institut National de la Statistique, Yaoundé.

Submit or recommend next manuscript to SCIRP and we will provide best service for you:

Accepting pre-submission inquiries through Email, Facebook, LinkedIn, Twitter, etc. A wide selection of journals (inclusive of 9 subjects, more than 200 journals)

Providing 24-hour high-quality service

User-friendly online submission system

Fair and swift peer-review system

Efficient typesetting and proofreading procedure

Display of the result of downloads and visits, as well as the number of cited articles

Maximum dissemination of your research work

Submit your manuscript at: http://papersubmission.scirp.org/

Or contact epe@scirp.org 